\title{
Negotiating Architecture Worlds in Indonesia: The Work of Eko Prawoto
}

\author{
GRAEME MACRAE
}

\begin{abstract}
The notion of 'art worlds' is useful for thinking about meetings of meaning in art, and by implication architecture, across boundaries of nation, culture and identity. Because architecture is less easily separated than some other arts from the conditions of its material production, it inevitably sits, often uneasily, between these material conditions and its status as 'art'. The aim of this article, which began life as an exploration of the relationship between contemporary architecture and national identity in Indonesia, is to adapt the notion of 'art worlds' to architecture and to use it to consider the production of contemporary architecture in Indonesia, especially by reference to the approach of one architect who explicitly thinks and speaks of his work in terms both of 'art' and 'worlds'.'
\end{abstract}

Keywords: Indonesia, Jogjakarta, architecture, art, critical regionalism

\section{Art, 'Art Worlds', Architecture and Indonesia}

The notion of 'art worlds' is useful for thinking about meetings of meaning in art, and by implication architecture, across boundaries of nation, culture and identity. But it is not necessarily linked to the political and economic conditions in which works known as art are produced. Because architecture is less easily separated than some other arts from the conditions of its material production, these political and economic factors are less easily overlooked. Architecture inevitably sits, often uneasily, between these material conditions and its status as 'art'. Consideration of architecture thus leads us back to 'art' itself-the slipperiest concept of all. The aim of this article, which began life as an exploration of the relationship between contemporary architecture and national identity in Indonesia, is to adapt the notion of 'art worlds' to architecture and to use it to consider the production of contemporary architecture in Indonesia, especially by reference to the approach of one architect who explicitly thinks and speaks of his work in terms both of 'art' and 'worlds'.

A recent book by Paul Stoller (2009) provides a useful point of entry into these relationships, grounded in empirical experience, but 
informed also by ideas from Shelly Errington (1998) and Stuart Plattner (1996). Stoller locates the origins of the modern international art world in Western Europe in the late nineteenth century: characterized by the potent combination of an ideology of a 'transcendental' quality that defines true 'art', the development of cultural-economic networks of 'avant-garde artists, dealers, critics and collector-connoisseurs' and an aesthetic of display based on the style of the great museums (2009: 100). He then shows how the products of other art worlds, specifically African wood sculpture and ceramics, have entered into this art world since the 1950s and have been given meaning and value by it. But this occurs only when they are stripped of the meanings (usually embedded in their modes of production) of their original art worlds and re-packaged within the tripartite framework of the Western (but now international) art world (2009: 100-102).

Stoller then goes on to show how West African men of his acquaintance in New York, whose livelihoods consist of importing artefacts from their homelands into America, effect a cultural translation across art worlds, transforming African 'wood' (sculpture) and 'mud' (pottery) into international 'art' (2009: 104-115). The point here, for our purpose, is that these translations are from art worlds in which meaning, or more precisely value, lies in the conditions of production and intended uses of objects, rather than the value structure of the international art world. This brings us simultaneously to architecture and to Indonesia.

Works of architecture, or at least certain works of 'Architecture', have long been recognized in the West as legitimate inhabitants of the art world of painting, sculpture and classical music. But not all architectures are equal and there has always been a majority of rude vernacular or utilitarian buildings that has fallen outside the domain of art. The value and forms of such buildings are determined by another architecture world defined largely by utilitarian purpose, available technology and budget. But even the grandest of buildings are at least constrained by these factors, too. Their status as 'art' however, lies in their claim to transcendence of these constraints to achieve aesthetic qualities and meanings above and beyond their utilitarian function. In other words, certain buildings become 'Architecture' through a process of translation across architecture worlds, from one defined largely by utility and budget to one defined by the conventions of the art world of the time. As in the case of African 'wood' and 'mud', this re-evaluation involves an abstraction away from their utilitarian function and also from the (often socially violent and conflicted) conditions of their production. 
The development of the modern international art world described above coincided with a massive technological modernization and industrialization of the building industry on both sides of the north Atlantic. Multiplication and endless repetition of mundane, mediocre building forms spread rapidly across urban and suburban landscapes. It also led to dynamic and spectacular new techniques, forms and especially scales of construction: skyscrapers, bridges, freeways. Both challenged the conventions by which architecture had been admitted to the dominant art world.

A small group of avant-garde architects, some with vital connections in the art world, laboured to effect the translation necessary for the new architecture to be admitted into the newly revised art world. A key element of this translation was the idea of an aesthetic universally appropriate across regions and cultures, embodied in the term 'international style'. This master metaphor, strategically managed and manipulated, especially by Philip Johnson (museum curator then architect), enabled modern architecture to re-enter the international art world, via the Museum of Modern Art (MOMA) in New York (Lefaivre 2003: 24), not coincidentally, the very portal through which African 'wood' and 'mud' would also enter the same world several decades later.

The combination of the disciplinary hegemony of the international style and its status as art, left little room in either the house of architecture or that of art, for other architecture worlds: whether of past styles, of other cultures or even of the everyday design/building practices of ordinary people. But, as with African art and later with the manifold forms of popular culture, these were eventually 'discovered' and brought, by the usual process of translation, into the dominant art world.

In the case of architecture, the exotic forms of traditional societies were translated across art worlds by way of the metaphor of 'vernacular' architecture, or more explicitly, 'architecture without architects' (Rudofsky 1964). The subtitle of Rudofsky's book, 'an introduction to non-pedigreed architecture', draws attention to the underlying primacy of provenance in the value system of the dominant art world. The legitimacy of this translation was established only by recognition of its transcendent aesthetic qualities over and above its lack of pedigree and only when duly authorized by the standard means of an exhibition at MOMA.

More challenging though, for international style practitioners and advocates was the recognition, during the 1970s, of a resurgence of contemporary work outside the international style paradigm, characterized by references to distinctly local landscapes and environmental 
and cultural influences. This counter-tendency, identified and labelled 'critical regionalism', amounted to an assertion of multiple architecture worlds, grounded not in any universal aesthetic, nor even primarily in aesthetics at all, but in the more concrete domain of local materials, conditions, histories, practices and cultures (Lefaivre \& Tzonis 2003; Frampton 1983). The ferocity with which this recognition of the regional was resisted by the gatekeepers of the architecture world is intelligible only in terms of the threat it implied to the hegemony and thus the status of the international style within the art world, and ultimately to the vested interests of its advocates.

Critical regionalism has since faded as a significant force in architectural criticism and scholarship, partly through absorption into the broader celebration of diversity of postmodernism, and partly by an intensified globalization of architectural practice, sometimes glossed 'world architecture'. Yet the work it referred to and the impulse underlying it remain.

For architects working far from the transatlantic centre of gravity of the international architecture world, however, the relationship between this world and the more or less local environments within which they work is an unavoidable matter for negotiation. This is all the more so for architects working in post-colonial countries, where a part of their historical heritage usually involves a legacy of incorporation into an earlier international architecture world by way of the work of colonial architects.

In Indonesia, the ethnographic locus of this essay, the manifold architecture worlds of local traditions were overlaid by the more or less transatlantic world of Dutch colonial architecture, which was in turn rejected by a post-colonial elite seeking to establish Indonesia as a modern, independent nation. Since then, Indonesia's political, economic and cultural relationship with the world has been through several shifts characterized by a shifting pattern of tensions between predictable globalizing forces and a range of influences more grounded in local political and cultural realities. The subject of this article is contemporary architecture in Indonesia and the way in which its practitioners experience and negotiate these tensions in the form of dissonant architecture worlds. I focus largely on the work of one architect, Eko Prawoto, whose work is widely recognized internationally as well as locally and whose recognition is as much as an 'artist' as an architect. His work is grounded firmly in both the most modern/international and the most local/traditional of architecture worlds, yet he negotiates and integrates them in ways 
that, I argue, give new life and meaning to the prematurely time-worn concept of critical regionalism. I further argue that his work is at once an illustration of a meeting of art worlds but also of the inseparability of art worlds from wider political-economic contexts.

\section{Indonesia}

For the nation of Indonesia, the management of its vast cultural, linguistic and religious diversity has been one of the overwhelming challenges throughout its first six decades of independence. A parallel challenge has been the management of external relationships with the international community. The first president, Sukarno, struggled with both and was eventually overwhelmed by them. The second president, Suharto, substantially reversed Sukarno's somewhat anti-Western foreign policy but intensified his control over internal diversity.

Indonesia now appears to be at a turning point as a nation: over a decade on from the sudden demise of Suharto's New Order, a semblance of political order has begun to emerge out of a period of disorder. Democracy of a kind is taking root; relatively free elections are held regularly, and in 2009, a president widely respected both within and outside the country was elected for a second term by a substantial majority with almost no accompanying violence.

Likewise, the central ideological (and when that failed, military) labour of the New Order - to contain and repackage the extraordinary ethnic and cultural diversity of a sprawling archipelago into a model of unified national culture - has continued by other means. The systematic devolution of administrative responsibility to districts (kabupaten) rather than provinces has to some extent undermined consolidations of local ethnic sentiments by subdividing ethnic populations. Nevertheless, persistent separatist movements at both ends of the archipelago (in Papua and Aceh), although rooted at least partly in political and economic problems, remind us that local ethnic/cultural sentiments remain strong and, like religious sentiments, cut deeply across any sense of national identity.

A third axis of diversity concerns Indonesia's relationship with the global economy. This was evident in the policy positions of the three presidential candidates in the 2009 election. The successful incumbent, S. B. Yudhoyono, inclined toward controlled liberalization and internationalization of the economy. At the other pole, Megawati Soekarnoputri campaigned for protection of small-scale, local and community economic 
priorities, reflecting the concerns of 'little people' over the economic effects of globalization. The third and least successful candidate, Jusuf Kalla, positioned himself somewhere between the other two.

While the art and architecture worlds of Indonesia only sometimes reflect this broadly sketched political environment directly and explicitly, it nevertheless forms the unavoidable backdrop to and grounding of them, without which they cannot be properly understood.

\section{Globalization and Architecture}

One of the first and arguably most successful examples of cultural globalization was the spread of modern architecture during the first half of the twentieth century. The term 'international style' reflects the vision of its creators and propagators, on both sides of the north Atlantic, of a truly global style that would transcend and replace all historical precedents, national boundaries and geographical variations. By 1952, one of the foremost proponents of international style, Philip Johnson, was able to claim (prematurely as it turned out) that 'the battle of modern architecture has long been won' and 'the International Style has spread and (has) been absorbed by the wide stream of historical progress...modern architecture has come of age' (Lefaivre 2003: 27-28) (Figure 1).

International style originated on both sides of the north Atlantic in the early twentieth century and was spread throughout Asia and Africa by the established European colonial regimes, who had previously disseminated their own distinct national styles: French in North Africa and Indo-China, British in India and Malaya, and Dutch in the East Indies, the islands now known as Indonesia (de Vletter 2006; le Roux 2004: 441). In the last case this led to some creative, interesting and often appropriate fusions of European and local styles, 'a synthesis of two elements: the modern constructive spirit, born of a rationalistic and intellectual knowledge that is universal and therefore eternal, and the spiritual, aesthetic elements that are particularistic and therefore everywhere different' (Kusno 2000: 32, paraphrasing Dutch architect H. P. Berlage).

Berlage was speaking in 1924, as the international style, of which he was a prominent forerunner, was becoming established in Europe but had not yet been exported to the colonies. He was referring to his visit to the East Indies during which he met a number of Dutch architects who were trying to develop a new architecture, distinctive and appropriate to the East Indies. Arguably the finest, and certainly the best-known product of this movement, were the buildings of the Bandung Techni- 
FIGURE 1: International Style: Le Corbusier's 'Unité d'Habitation', Berlin

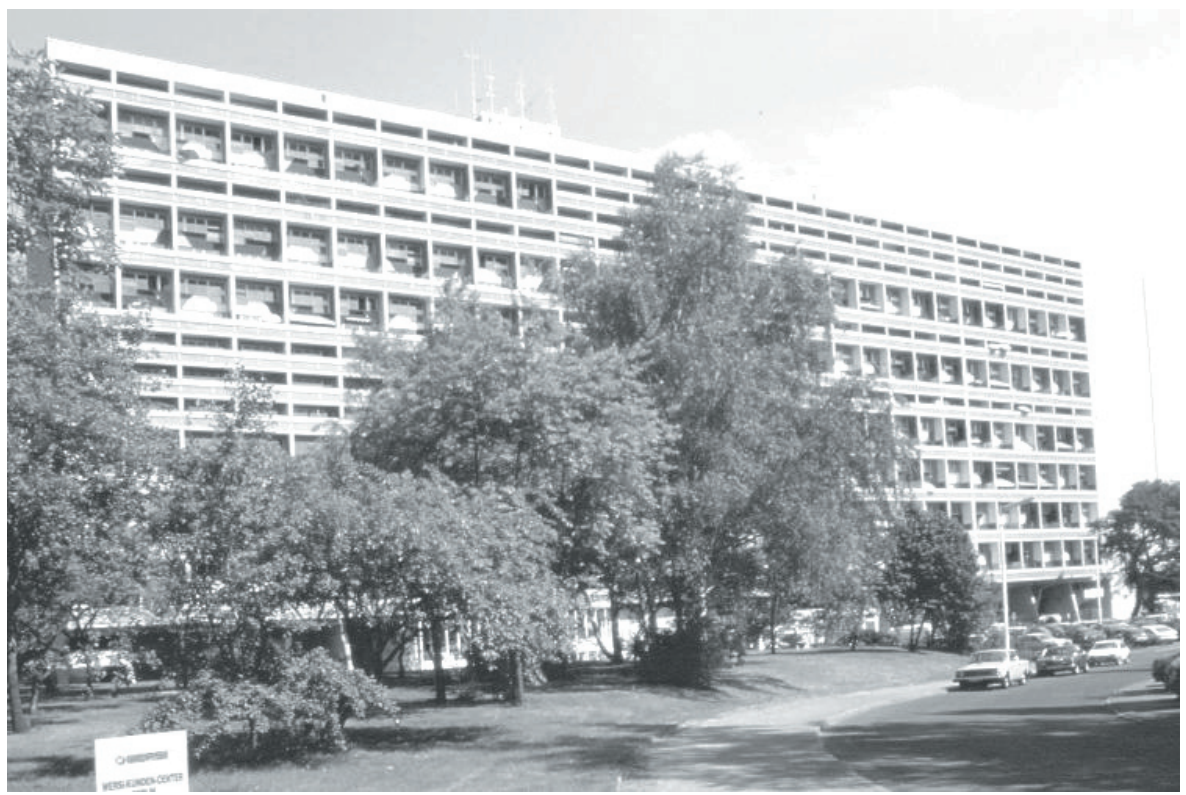

Photograph by Shaqspeare

cal College (now Bandung Institute of Technology [ITB]), designed by Henri Maclaine Pont. While the purpose of the school was to inculcate the local elite with the values and methods of modern technology, the design of the buildings sought to combine these with an aesthetic and spirit derived from local traditions.

By the time of independence, however, more standardized forms of international modern architecture had come to dominate in most colonies and traditional and neo-traditionalist styles were in decline or retreat. After independence, the new nations struggled to find their economic and political paths, but also their cultural identities. Hannah le Roux (2004), in an insightful discussion of post-colonial architectures in tropical Africa, interprets a portrait of one of the pioneers of Nigerian modern architecture, standing on a balcony of one of his modernist buildings but dressed in traditional robes and looking away to the sprawling market and city beyond, to suggest 'an intense desire for a space that is both modern and open to its context, that mediates between identities'. She concludes that 'for architects practising in non-western locations...modern architecture [is] a heritage that is both binding and rich with possibility' (2004: 450-451). This is true for Indonesia, but so also I suggest, is its converse, that the heritage of traditional styles is equally a storehouse of possibilities and limitations. 


\section{Sukarno's Modernist Vision: National and Architectural}

Cultural production, including architecture, has long been one of the means used by ruling elites to establish, demonstrate and maintain their visions of appropriate national identities (Gittus 2002: 91; Lico 2003; Sudjic 2005). In the case of Indonesia, the first president, Sukarno, happened to be one of the first architect/engineers trained at the Bandung Technical College. He was also a brilliant visionary nationalist who chose to 'design his nation instead of...buildings for the Dutch elite' (Kusno 2000: 46). But he used architecture quite explicitly to articulate and advance his vision of the nation.

The slate on which Sukarno worked was a relatively clean one because, unlike in India or some of the new nations in Africa, there was little in the way of national architectural tradition to design against, for the simple reason that the nation had never existed before, except in the inverted form of colonial subjection. What there were, of course, were multiple local architectural traditions, at the levels of ordinary housing and in some areas, more elaborate traditions of palace and temple architecture, culminating in such extraordinary monuments as the Prambanan and Borobudur temple complexes in Central Java. But the former were highly localized and the latter were of distinctly Indic origin and neither sat easily with the dominant meanings of Sukarno's unlikely ideological blend of nationalism, religion (meaning, in effect, Islam) and communism. ${ }^{2}$

Sukarno's architectural mission was, to all appearances, a modernist one, founded in a vision of an Indonesia freed from the shackles of colonialism, but looking forward to a future in an international arena of modern nations, rather than back to its traditional past(s). This vision was articulated in a series of large monuments, roads and skyscrapers in the capital city Jakarta.

The modernist architectural form of Sukarno's vision has been well documented (Anderson 2006: 173-174; Nas 1993; Leclerc 1997; Macdonald 1995; Dovey \& Permansari 2010), but appearances can be misleading. A recent study (Kusno 2000: 68) notes insightfully that while the architectural image (of modernism) may be constant, its 'denoted meanings' may vary according to local contexts, meanings and intentions. Behind Sukarno's modernist aesthetic, Kusno argues, was an attempt to establish a symbolic centre of power, founded less in the supposed rationalities of modernist planning, than in ancient Javanese (originally Indic) notions of the expression of cosmic sources of political power in spatial and architectural forms (2000: 60-62). Modern/international architectural 
style may be understood in Sukarno's Indonesia, as what Anna Tsing refers to in another context as 'travelling allegorical packages', which, uprooted and ideologically separated from their actual origins in very specific historical and cultural contexts, take on new meanings as they take root in new historical/cultural contexts (2005: 215, 234, 238).

Kusno's insight raises the new and more difficult question of 'why modernist architecture was understood by Sukarno in a way that expressed the aspiration of Indonesia' (2000: 68). Kusno's answers are inconclusive, beyond recognition of an obvious desire for Indonesia to take its place as an equal in a world of modern nations and the capacity of a universal aesthetic to take on particular local meanings. He does, however, end with the observation of an inherent 'ambivalence' and 'contradiction' at the heart of Sukarno's vision of the nation. ${ }^{3}$

I am inclined to take Kusno's conclusion a step further and suggest that while the outward form with which Sukarno represented his 'imagined community' was modern, the imagination with which he envisioned it was deeply traditional. This is perhaps not surprising given the conjunction of history and circumstance facing the country. But neither should we be surprised if such ambivalence and contradiction (and especially attempts to reconcile them) between form and meaning, modernity and tradition, universal and local, turn out to be recurring themes in Indonesia's attempts to represent itself to itself.

\section{The Architecture World of the New Order}

Sukarno was in the end never able to complete his monuments, let alone reconcile these philosophical contradictions, but he was ironically undone by other more mundane political-economic contradictions in 1965. A regime that came to be known as the New Order, headed by General Suharto, took over in dramatic and bloody circumstances in 1965-1966 and remained in power until 1998. It was a highly centralized, authoritarian, military-backed regime that never hesitated to use force to control its people; but its preferred method of control was an ideology of national unity, political stability and development inculcated through the administrative and education systems. Art and culture were subsumed into the service of this ideology, mostly in the form of politically sanitized styles and performances, in which any traces of local, let alone ethnic, art worlds were reduced to superficial tokens of 'cultural diversity', surface decoration covering any cracks in the façade of political unity (Acciaoli 1985; Pemberton 1994a). 
The architecture world of the New Order was consistent with this model. On one hand, the opening of the country to foreign investment and the emphasis on economic development led to a proliferation of (mostly mediocre) copies of mainstream modernist construction, especially commercial building in the urban centres. On the other, it introduced and celebrated tokenistic representations of 'traditional' styles. The apogee of this was the much-documented 'Beautiful Indonesia in Miniature' theme park (Taman Mini) in Jakarta (Anderson 2006: 176-177; Errington 1998: 194-199; Pemberton 1994b; Hitchcock 1997; Kusno 2000: 74-78). Taman Mini is essentially a large outdoor museum, purporting to represent all the diverse cultures of the nation, primarily in the form of somewhat idealized replicas of their 'traditional' houses.

Such folksy tokens of the traditional, 'the sweetness and sentimentality that often accompanies power' (Easterling 2005: 8), also flourished routinely, almost ritually, often by government decree, as surface decoration on otherwise undistinguished government buildings and tourist hotels (Nas 2003: 142). A part from these tokens, traditional architecture worlds survived only in minority enclaves such as Bali, Toraja and parts of Sumatra, often (but not always) in symbiotic relationship with culture-focused tourism (MacRae and Parker 2002; Reid 2002; Allerton 2003; Vellinga 2003). This gap between modernist practice and traditionalist decoration was rarely recognized, let alone consciously articulated or bridged.

Kusno (2000) discusses two exceptions, both on campuses of major state universities in which issues of national identity were paramount. The centrepiece of the Bandung Institute of Technology (ITB) is one of the architectural landmarks of the colonial period, a complex of buildings based on traditional Indonesian styles designed with specifically transcultural intentions by the Dutch architect Henri Maclaine Pont (Figure 2). When the campus was extended, largely to accommodate new scientific and technology facilities in the early 1990s, there was a need to find some accommodation between the new buildings and the old core. The solution chosen was to divide the campus into three zones: the original one, now designated 'konservasi-historis'; a new 'modern' zone, occupied by technology laboratories in a strident international postmodern style; and a 'transisi' zone that links the two, in which the buildings are functionally, technically and internally modern, but clothed in exterior forms and especially roof shapes that echo those of the Maclaine Pont originals. It is a neat architectural solution, a strategic juxtaposition and joining of architecture worlds expressing a 
FIGURE 2: Bandung Institute of Technology, Original Maclaine Pont Design

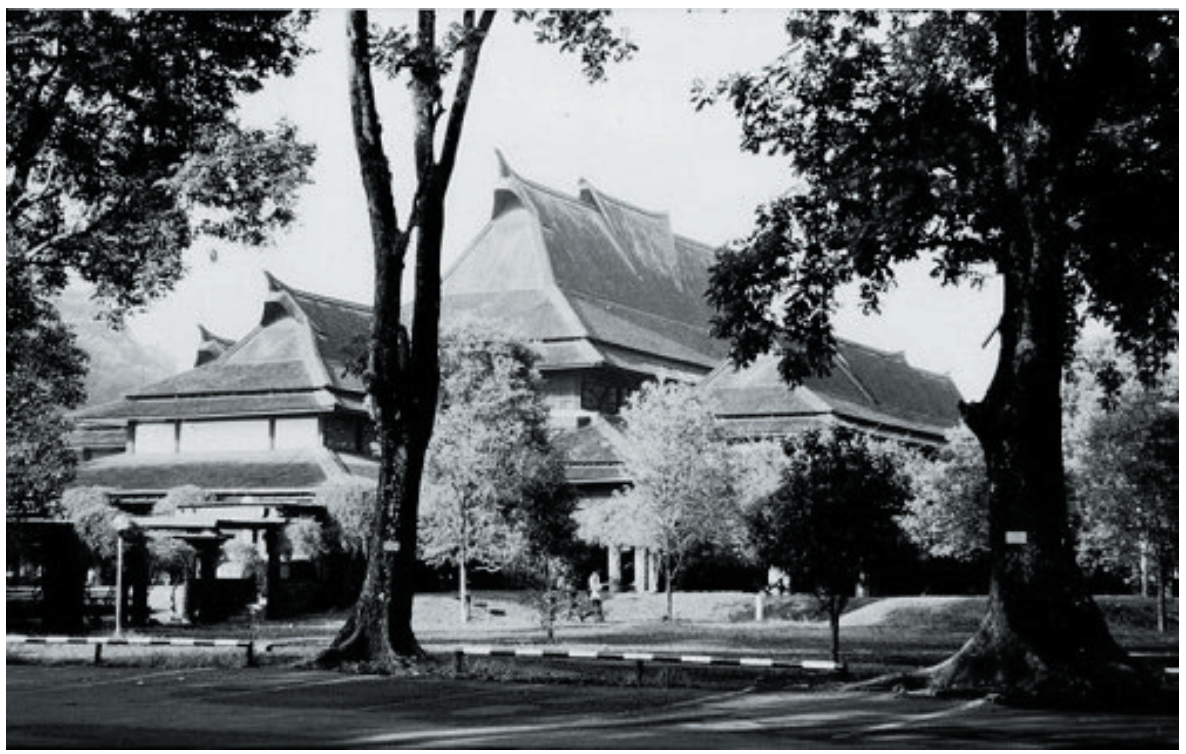

Photograph by Merbabu

periodization of history distinctive to the New Order mythology of the nation. Kusno, however, sees the vocabularies, architectural as well as nomenclatural, as simply an erasure of the realities of national history. Ironically though, its colonial/Indonesianist origins are forever embedded in the overall site plan (Kusno 2000: 81-85).

At around the same time, the University of Indonesia (UI) began building a new campus on the southern fringe of Jakarta. In this case, the need for expression of national identity was even more explicit and the architectural worlds of the nation were consciously reviewed and mined for ideas and models (Kusno 2000: 85-86). The result incorporates planning principles of Indo-Javanese cosmic centrism and of the Javanese pendopo pavilion, Balinese ideas of tripartite hierarchy and tiered roofs, as well as generically archipelagic pavilion/roof forms all superimposed on more or less conventional modernist buildings (see Figure 3). The effect is not unlike that of the zona-transisi at ITB, but according to Kusno, the logic is different; it is more a repetition of the Dutch invention of tradition than an accommodation to the visible traces of colonial history (2000: 86-88).

This brings Kusno to one of his main arguments: of 'a fundamental split... a contradictory identity that, on one hand, gives rise to the coloniality of "Indonesian architecture" and on the other hand, a denial 
FIGURE 3: University of Indonesia, 'zona transisi'

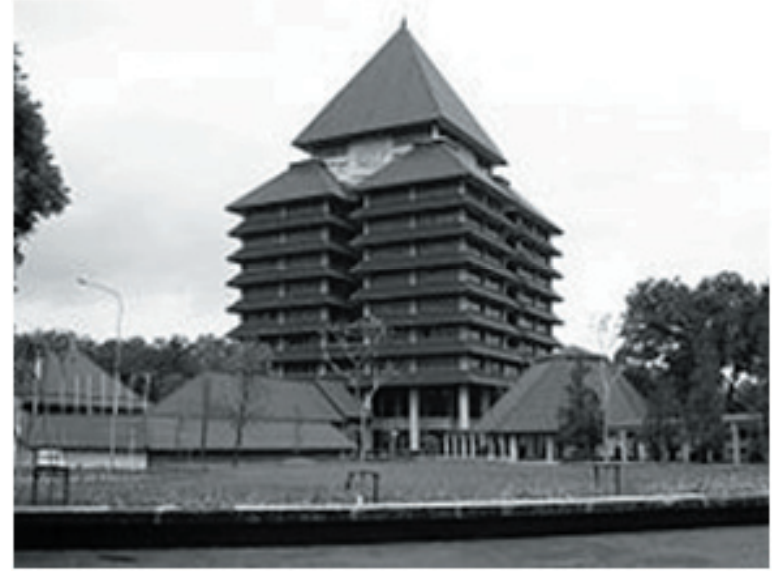

Photo: Tequendamia

of its colonial origin' (2000: 88). The stylistic similarity but opposed meanings of the two university designs would appear to embody this contradiction in architectural form.

I suggest that what Kusno has identified is a deep contradiction, not only in architecture, but in much of contemporary Indonesian culture including its art world(s). But it reflects also a set of more obvious tensions that I am concerned with here, and which have become especially evident in the post-New Order period, between notions of 'tradition' versus 'modernity', 'localness' versus 'globality' and 'particularity' versus 'universalism'. These are the axes along which local debate about culture has largely turned since the New Order period.

\section{National Identity, Culture and Architecture in post-New Order Indonesia}

The New Order regime ended in May 1998, as abruptly as it began. Less blood and fewer tears were shed than in 1965, but the ensuing economic crisis and political turmoil is only now, more than a decade later, beginning to settle. This has been a period of reformasi (reform) of political and administrative orders, but also one in which Indonesians have had to reimagine and rebuild their nation in terms of identity and culture as well as political and economic order. One key aspect of reformasi has been desentralisasi, a devolution of budgets, decision-making and democratic process to lower, more local levels of administration. However, the level to which official autonomy has been devolved has been the 
district (kabupaten) rather than the province. Ethnic identities tend to correspond more to the provincial level, so this arrangement has tended to internally divide rather than reinforce local ethnic identities (Buehler 2007: 119). While this has also weakened central control over cultural production, a new diversity of local cultural production has flourished, but not always directly correlated to local identity politics.

Contemporary architecture in Indonesia is dominated by what might be described as a global/modernist paradigm, in economic, aesthetic and philosophical terms. The majority of architects are unashamedly in the business of business. Many double as contractors and/or developers as well as designers. The more affluent metropolitan centres of Indonesia have sprouted concentric rings of commercial buildings, shopping malls and housing estates. These are designed to serve the consumer tastes of the growing middle class and the commercial interests of their investors. Aesthetically they are (often cheap and shoddy) knock-offs of similar building forms found anywhere else in the world. Traces of 'traditional' styles are visible in these kinds of buildings only in occasional token displays of applied ornament. Less affluent areas are sprawling masses of smaller, cheaper, shoddier and even less-designed versions of the same range of forms, but usually spared the pretence of 'traditional' decoration.

The practices and forms of traditional building have virtually disappeared except in two areas. One is the everyday architecture of the poorest and most rural people who continue to build rudimentary shelters using much the same methods and in some cases the same materials that have been used for centuries. This practice is driven by expedience rather than any sense of tradition.

The other is in certain parts of the country where more conscious notions of local identity and traditional culture are strong. This occurs for various reasons, but it is often related to and financed by tourism. For example in Bali, where a sense of distinctive Hindu culture is also a significant tourist attraction, traditional architectural forms and practices remain alive and well in the endless renovation, extension and reconstruction of temples and, to a lesser extent, private houses (MacRae and Parker 2002; see also Reid 2002; Waterson 1997: 234-242). In such cases, ideas of cultural tradition and local/ethnic identity are central to the continuity of practice, but they involve a self-conscious looking backward to tradition, often resulting in somewhat reified interpretations. These are best understood in terms of reaction to rather than engagement with modernizing, globalizing or national- 
izing forces.

What is conspicuous by its rarity in any of these practices, however, is any sense of creative or critical engagement between local cultural heritage and ideas, practices or aesthetic models drawn from wider and more modern sources. In other words, these architectural forms float in a timeless zone more or less disconnected from the changes that have affected the rest of everyday life. There are, however, a minority of architects who do think about what it means to be designing and building in a distinctively local, national or regional environment, cultural as well as physical. These designers also tend to be as global in their influences as local. Some of them are Indonesians who work internationally as well as locally. Others are local, with practices initiated and driven largely by foreigners. What I would like to focus on here is one architect whose work seems to me to be especially interesting and which seems to reflect a sophisticated awareness of different architecture worlds and conscious engagement with the problems raised by their intersections in practice.

\section{Eko Prawoto}

Eko Prawoto is an Indonesian architect, born a decade after independence and trained in Indonesia and Europe. He practices as an architect mostly in and around Jogjakarta and teaches in the architecture school of a local university. He is also an artist and attends art events all over the world. His career has spanned from the late New Order period onward. His architectural work consists largely of private houses, art galleries, churches and small commercial buildings in and around Jogjakarta. ${ }^{4}$

His buildings range in aesthetic style, at least at first glance, from the 'modern-looking' to the 'traditional-looking', the 'local' to the 'international' and more often combinations of the two. They often combine large, open, airy spaces with intimately scaled, private ones, cheap industrial materials with materials found in traditional villages and recycled elements from old buildings and junkyards. They have no air conditioning and minimal glass, and rely on natural ventilation, verandahs and courtyards, often incorporating semi-interior trees, gardens and pools to moderate the tropical climate (see Figures 4, 5 and 6).

His buildings are comfortable and user-friendly, often beautiful and always interesting. While they are not especially spectacular, let alone ostentatious, what is most striking is their almost complete lack of resemblance to any thing else in the contemporary Indonesian architec- 
FIGURE 4: Exterior of House Designed by Eko Prawoto

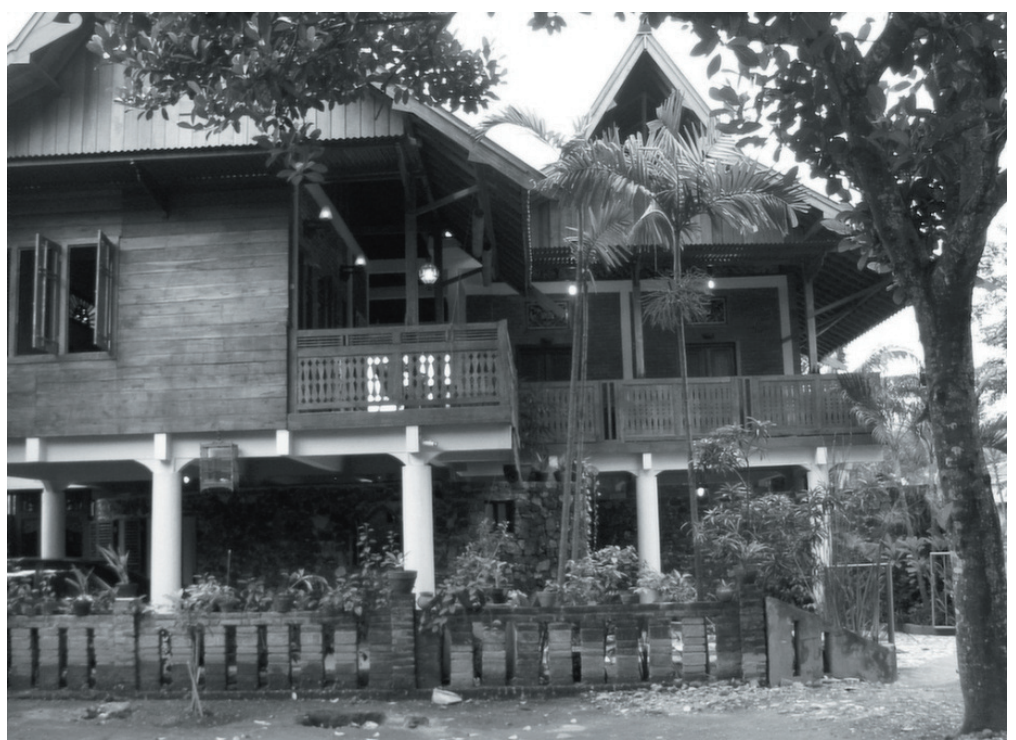

Photograph by Eko Prawoto.

FIGURE 5: Interior of House Designed by Eko Prawoto

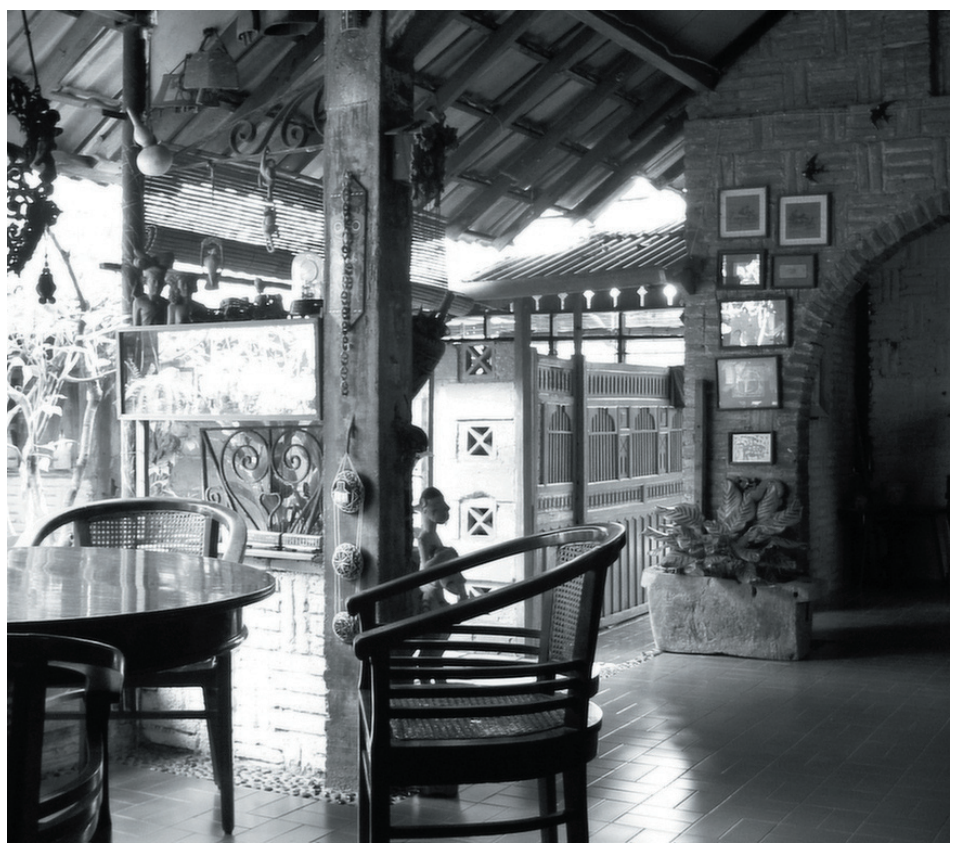

Photograph by Eko Prawoto. 
FIGURE 6: Exterior of House Designed by Eko Prawoto

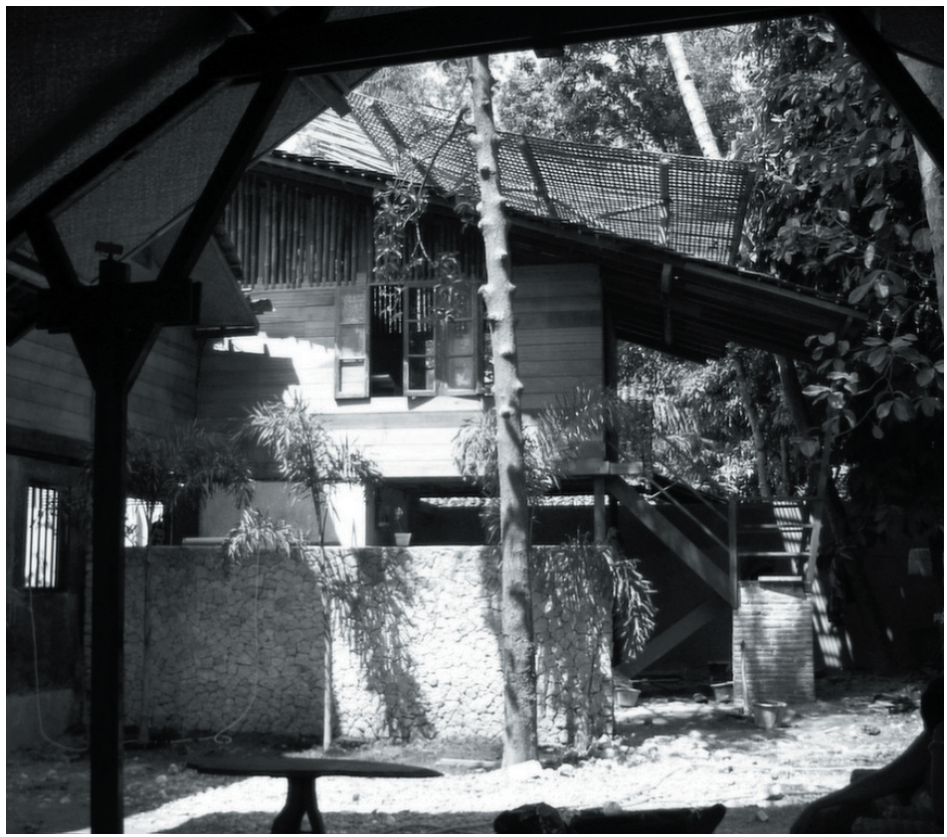

Photograph by Eko Prawoto.

tural landscape. If they resemble anything, it is simultaneously village houses, industrial sheds of the colonial period, Western arts and craftsstyle buildings or even the work of the pioneers of modern architecture (Pangarsa 2008: vii, 7, 25).

Eko's work has been described by an international historian of architecture (Goad, Pieris \& Bingham-Hall 2004) as 'an innovative quest for modernity and a critical questioning of the modern capitalist identity embraced since...independence', but also a 'form of resistance to the simplistic pictorial reproduction of...traditions' (2004: 118). This interpretation is suggestive in terms of architecture worlds, and I largely concur with it, but I would like to expand on it somewhat.

Unlike many architects, Eko is also eloquent in the medium of words, spoken as well as written, and he uses them regularly to reflect consciously on his work. In addition, his work in the artistic domain provides him with another medium for more direct expression of his ideas. It is to these that we need to turn to understand his work in relation to art/architecture worlds.

To fully appreciate the significance of Eko's work it is necessary to understand that his aims cannot be reduced to the domains of the artistic or the architectural in any narrow sense of the terms; they com- 
bine aesthetic values with others that might be described in terms of humanitarianism, social and environmental values, cultural heritage, participation, community-based development and identity. While a sense of creative tension between art worlds is but one of these themes, it is in practice intimately interwoven with the others.

In August 2008, to celebrate 50 years of life, 25 of them as a practicing architect, Eko held a two-part exhibition entitled Leng/Lung (see Figure 7). Leng is a Javanese word meaning a deep, inner place, such as a pool in a river, a cave or the burrow in which an animal lives. Lung refers to a creeping/climbing plant and its distinctive movement, especially of outward growth. It is also the root of a verb (nglunge) meaning to walk, or more generally, to go. Leng suggests a staying home and going inward, lung suggests going out into the world.

The first part of the exhibition (Leng), in a closed gallery (designed by Eko), consisted of an empty space defined and enclosed by an inward spiralling wall of modular bamboo grates. The second part (Lung), at a sprawling artists' retreat (also designed by Eko) on the rural outskirts

FIGURE 7: Leng/Lung Exhibition, showing design of the Leng element

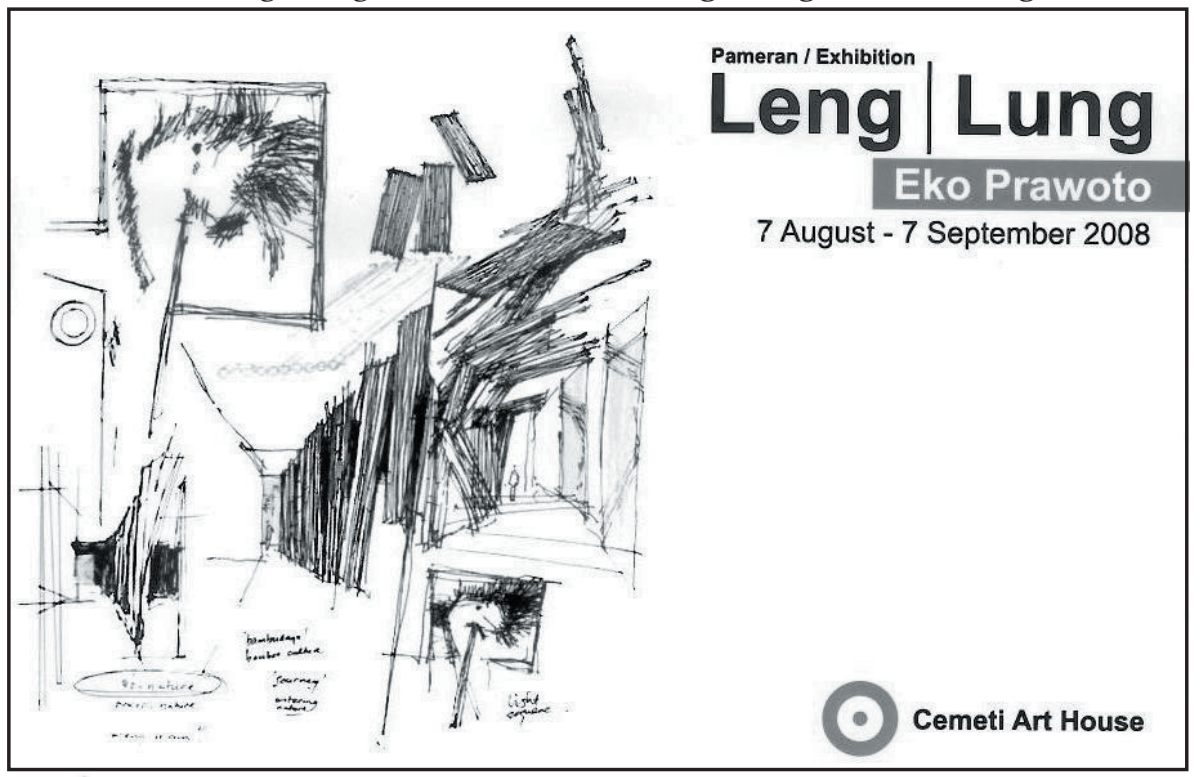

of Jogjakarta, consisted of a series of outdoor bamboo structures by a number of artists. Eko's own installation was rigorously geometrical in shape, but constructed of bamboo in his signature style of tall, natural, irregular stalks opening outward like the petals of a gigantic flower (Figure 8). 
FIGURE 8: Lung Construction (with Eko in the foreground)

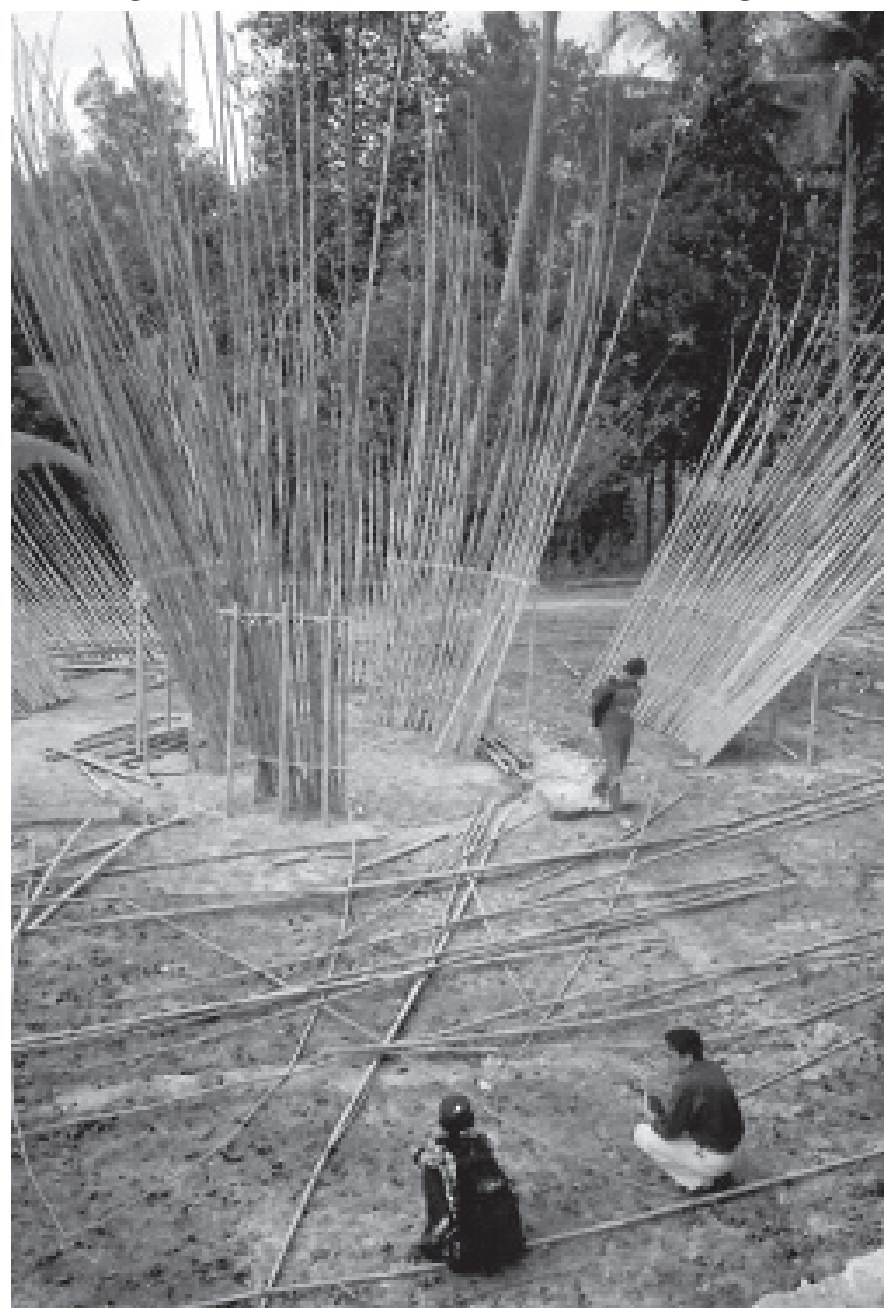

Photograph by author.

The invitation to the opening (Prawoto 2008a) contains a brief essay in which Eko writes about the way in which Indonesian culture is a historical 'result of global interaction', but contemporary globalization has sapped the creative energy (of Indonesia) and alienated Indonesians from their own cultural roots, leaving them a nation of passive consumers of foreign products, cultural as well as technological. This manifests at an individual level as a spiritual emptiness and at a social one as a loss of communal sentiments and practices. The answer to this alienation, Eko implies, lies in going deep within - into (the leng of) nature and our own nature, and the traditional cultures that serve to connect people with such natures. True development can only grow (lung) from these 
foundations, rather than from outside. ${ }^{5}$ The argument here suggests that Indonesian cultural identity is simultaneously a product of and threatened by globalization and that the solution is not to erect barriers against it but to work outward from an (unspecified) local identity rooted in nature and culture rather than nation.

Another element of the celebration was the launching of a book (Prawoto 2008b) of 100 of Eko's sketches from thousands he has made over the course of his career. What they record, as architects' sketches usually do, is some of the buildings, landscapes and scenes that have influenced his work as well as his thinking about architecture and public space. Those made during his travels as a student in Europe, and later in other parts of the world, are mostly of famous architectural monuments, modern as well as ancient. What they record are influences that range from the most famous monuments of modern architecture, to the distinctive buildings and spaces of classical cultures from Europe to Japan. About one-third of them, though, are of his own familiar home territory: Jogjakarta and

FIGURE 9: A Sketch by Eko Prawoto

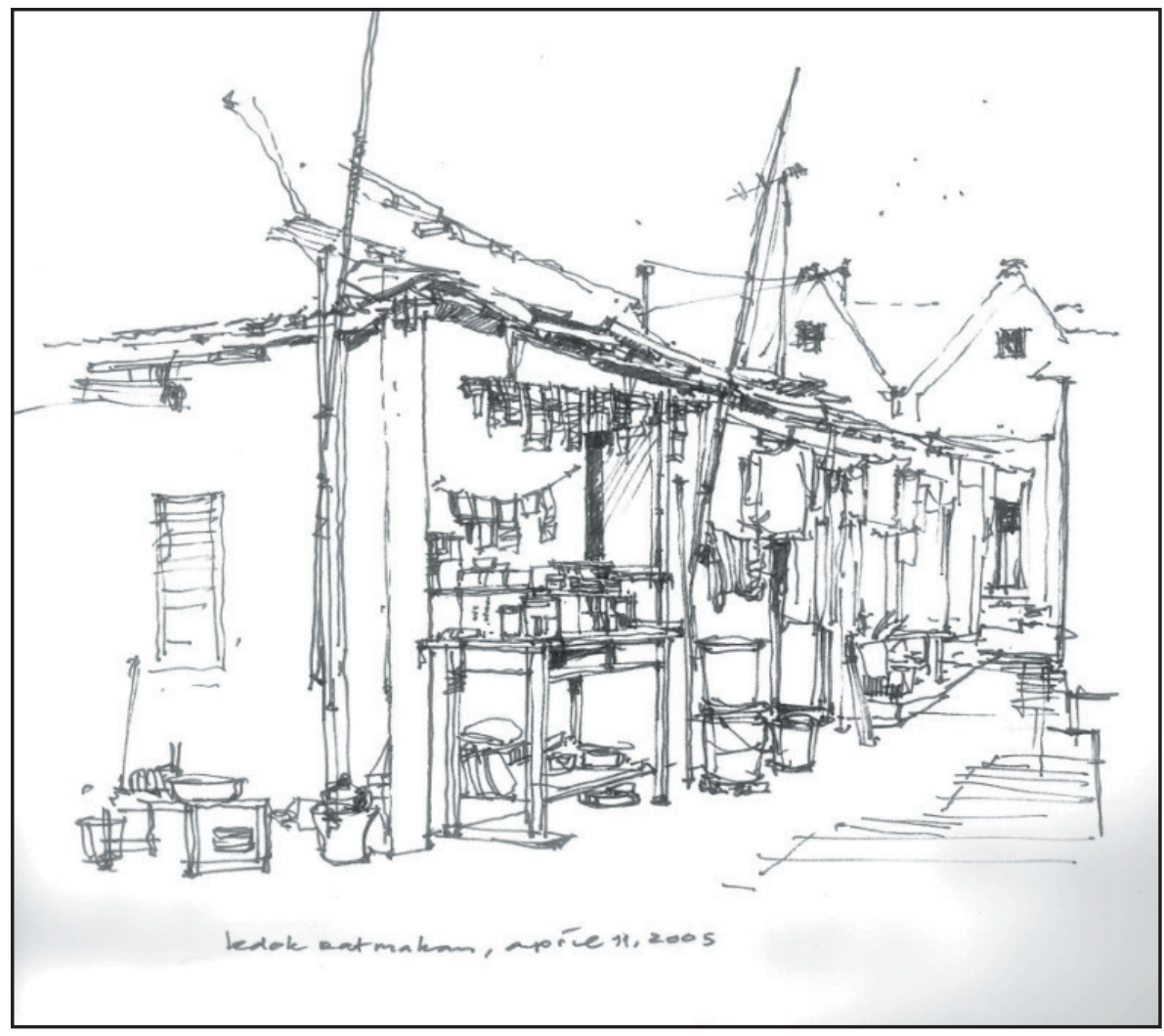

Used by permission of Eko Prawoto. 
the villages of the surrounding agrarian hinterland. Most of these are lovingly detailed studies of buildings and especially outdoor/public spaces in old kampungs (neighbourhoods) where the less affluent people, or those who prefer an older way of life, still live.

While the human figure is almost absent from these sketches, they are redolent with the traces of human habitation: clothes drying, bicycles and brooms leaning against walls, cooking and washing utensils, places to sit, work and eat. What Eko is exploring, analyzing and celebrating in these sketches is, I believe, not so much the spaces and structures themselves, but the human activities and way of life that are embodied in these places. In his own words,

Doing architecture means constantly related to...the atmosphere or the soul radiated by place. It is also expression of life, the embodiment of interactions between human activities and its setting and about human creativity as a response to life (Prawoto 2008b: 5; see also Raharjo 2010).

What these sketches also show us is a key part of what Eko means by his leng - the well-spring of his identity as an architect/artist-and it is in these humanized spaces of kampung life, but it is also in the places all over the world where he has recognized the same kind of leng and the beauties that lung from it in other cultural settings:

...I am... underlining localities...confronting uniformity of globalisation. ... Locality is not just an aesthetic exercise, but... finding the strategy to live in modern global setting without losing the socio-cultural roots. I use...local materials... local skills...techniques...strengthening the...community by appreciating local values (Prawoto 2008b).

In 2005, all of these ideas came together in an unexpected project. After an earthquake destroyed some 300,000 houses around Jogjakarta, the area was inundated by a tsunami of international relief agencies, providing first, emergency shelter, and then, reconstruction. While everyone was grateful for the assistance, some, including Eko, saw the way in which the relief operation was conducted as yet another form of globalization that neglected and ignored local, natural, social and cultural resources, marginalized local communities in the reconstruction of their own homes and villages and often created collateral damage in the process of trying to rebuild on behalf of people.

The national newspaper Kompas, which had launched an appeal to raise funds for assistance, contacted Eko and offered him modest funding for a reconstruction project. He went to a village that he knew well called Ngibikan, in which only one house out of some 120 was left standing, and talked with them about how they wanted to rebuild. Out of these 
discussions came a design for a standard house and a system for rotation of collective labour to build all the houses simultaneously. They started work within days and within three months they had virtually rebuilt the entire village, with elegant, light, airy, earthquake-resistant houses. This was by any standard an extraordinarily efficient project of reconstruction, especially in comparison to the international system, which was still trying to organize its resources to deliver temporary shelters. ${ }^{6}$ What is significant for our purposes is what Eko thought he was doing that made it so successful.

The main reasons Eko cited for the project's success were: (a) the ability to work out a realistic design quickly. This in turn depended on (b) existing building/design skills in the community, (c) strong solidarity and collective labour (gotong-royong) traditions in the community, (d) the absence of unrealistic or inappropriate expectations in terms of building style and materials, (e) local control and sense of community 'ownership' of the whole process, all of which were in turn dependent on (f) the small, face-to-face scale of the project. In other words, his approach to reconstruction was grounded in his confidence in the adequacy of

FIGURE 10: Building New Houses in Ngibikan

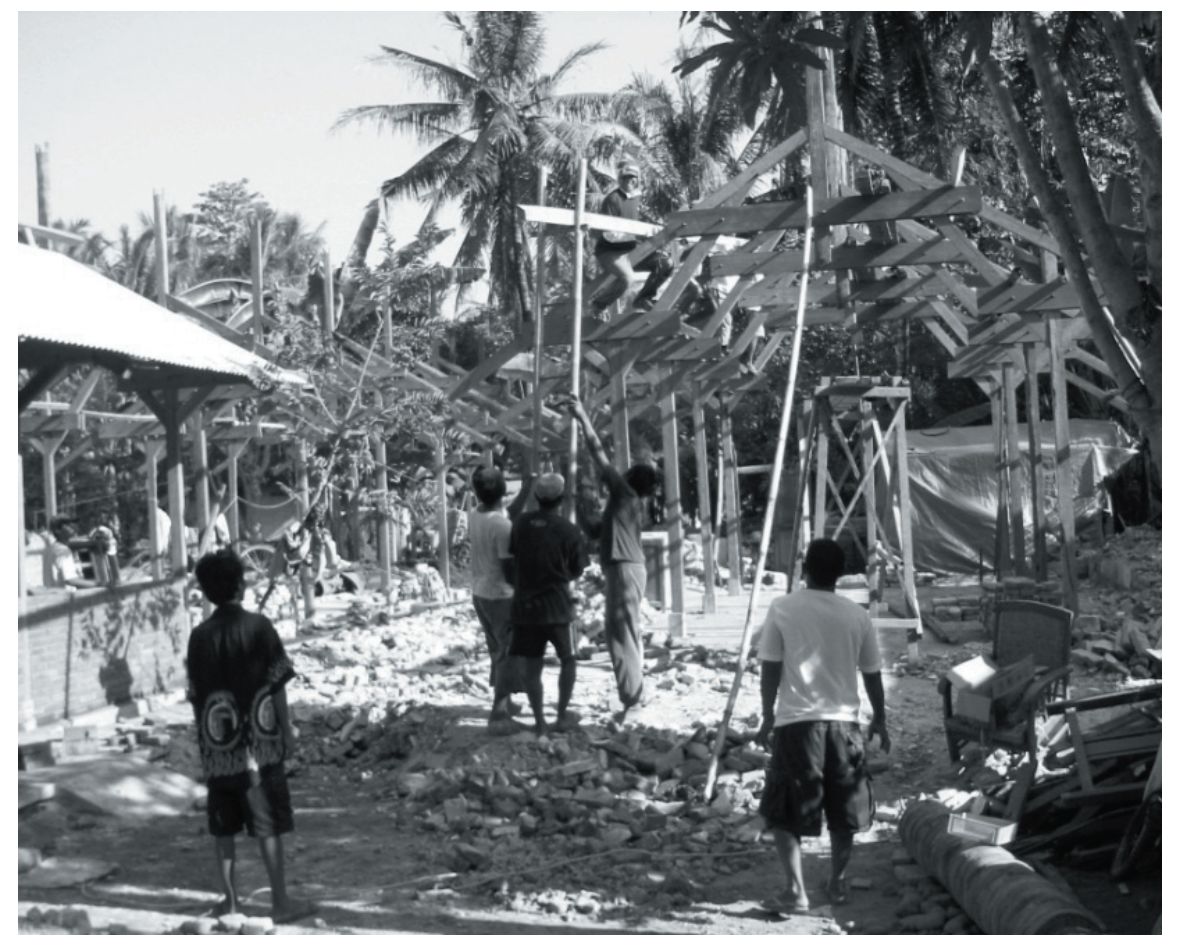

Photograph by Eko Prawoto. 
local resources, social and cultural as much as physical. He saw these as at least equal to those of the global system, but with the additional benefits of rebuilding not just houses, but communities.

This seems an illustration of his philosophy condensed to the essentials and stripped of the customary packaging that defines the location of objects in art worlds. By guiding the community into the leng of their own knowledge, skills, social traditions and natural resources, rather than imposing an outside/global solution, they were able to nglunge, to move/ progress quickly and effectively. ${ }^{7}$ Two points are important here. First, Eko was from the start sceptical of the social/cultural inappropriateness of the global system and saw this explicitly as an alternative to it, grounded in local resources. Second, it is also significant that his notion of local resources and identity consisted not of a preconceived form, but was to be found in the process of a community rebuilding itself through rediscovering its own knowledge and social practices.

\section{Provisional Conclusions}

From this very brief exploration of Eko's work, what is he saying to Indonesians and what does it allow us to say about national identity, globalization and art worlds? First and most obviously, it recognizes, indeed assumes that they are connected; globalization at best challenges and at worst threatens local communities, cultures and identities, certainly in Indonesia. Second, his proposed solution is neither to reject nor resist globalization, but to step sideways and find a place to stand and thus to address it from a position of strength. The method for this is to explore deeply and reconnect with natural environments, community practices and cultural traditions that exist only at local levels. Once we find this inner place from which identity arises, we can expand and grow and move outward in ways that enable us to deal critically and selectively with global influences on our own terms.

The art and architecture produced here is defined not in terms of a particular form or style but by a process of reflection out of which diverse and eclectic forms can arise. The communities, environments and traditions that Eko sees as the sources of this strength and cultural selfconfidence are not predetermined in geographical terms, but in practice they are grounded at local levels or even regional ones (e.g., 'monsoon Asia'), the loci of lived realities of community and environment.

While Eko is saying and doing all of this in the medium of architecture and art, he has implied all along that the principles apply more widely. 
The Ngibikan project demonstrates what he means, in the context of a humanitarian aid project, where 'architecture' is reduced to the most basic elements and formal 'artistic' imperatives are almost absent. Here the real work is the work of community, of identity - and both are conceived as alternatives to a hegemonic global model.

\section{Critical Regionalism}

Eko does not refer to his work in terms of critical regionalism, although he is aware of the concept, but it seems to me a useful framework for thinking about his approach and the meetings of local art worlds with the international art world. His work would also appear to extend the concept beyond its narrowly architectural origins and suggest that it may be a useful way of thinking more broadly about the meeting of architecture worlds.

The term 'critical regionalism' was first coined, more or less simultaneously, in the early 1980s by Kenneth Frampton (2007) and Liane Lefaivre and Alexander Tzonis (2003) (both drawing on Lewis Mumford) in relation to architecture and planning. It has been defined as

a bottom-up approach to design [that] emerged out of the specifics of an individual situation [and addresses] the ubiquitous conflict...between globalisation and...local identity... [by recognising] the value of the identity of a physical, social and cultural situation (Tzonis 2003: 11).

The term attempts to provide a catch-all label for a range of local architectural developments in various parts of the world during the late twentieth century that seemed to be 'working towards an alternative to postmodernism' (Tzonis 2003: 10). Postmodernism itself was, however, like the modernism it purported to critique and supplant, essentially another universalist global paradigm originating from the metropolitan centres. What was different, interesting and common to these developments was that they seemed to provide a quite different set of alternatives to the global postmodernism model, emerging independently out of local situations.

Using the term 'regionalism' shifted the emphasis from the temporally-framed axis of pro/contra-modern toward a geographical one of places and their associated social and cultural formations. The notion of 'region' though, unlike 'nation', is an essentially relational, rather than bounded term, sufficiently flexible to accommodate the ways in which ideas and practices actually form, flow and move in the real world. The adjective 'critical' reflects a fundamentally sceptical and resistant 
relationship with the processes of globalization, but also a conscious remove from idealized, essentialized, romanticized notions of the 'local' and 'regional' traditions and even more so the chauvinist and even fascist purposes they have on occasion been used to serve.

While the notion of critical regionalism has not been universally accepted (e.g., Colquhoun 1997; Eggener 2002), it is widely recognized, even by its critics, as having raised 'significant questions about modernity, tradition, cultural identity, and place' (Eggener 2002: 230) and is periodically revisited (Hartoonian 2006). What I would like to suggest here, albeit briefly, is that the concept of critical regionalism can be usefully adapted to a broader, more flexible, ethnographically grounded approach to thinking about the intersections of art worlds and also, by implication, that understanding the dynamics of art worlds cannot be usefully separated from wider 'community worlds'; these in turn cannot be separated from the political-economic contexts in which they are inevitably grounded.

The ideological labour of establishing an Indonesian national identity has, as we discussed earlier, been consistently undermined from both within and without. On one hand, there has been uncertainty over Indonesia's position in relation to global political and economic systems and on the other, the constant presence of local ethnic and religious identities, not to mention economic differences, has led to frequent disruptions of any sense of national unity (for recent but typical discussions see Sakai, Banks \& Walker 2009: 2-3; Kahn 2009).

Given this history, with the ultimate failure of the nation-defining projects of the Sukarno and Suharto regimes, the contemporary influences of global flows and processes that present a challenge to even the strongest of nations, and the backing-off of the present administration from the focus on national identity, it seems timely to wonder whether the old model of a centralized, top-down prescription of national identity is still realistic. What Eko's practice of architecture and practices of critical regionalism more generally suggest, is that approaching these problems in terms of meetings of art-, architecture- or more broadly culture-worlds may be useful, especially in the challenging conditions of globalization.

Such approaches begin not from identity or even from globalization, but from practice - the practice of architecture, or of art, or even something as pragmatic and urgent as rebuilding after a disaster-in other words, the practice of life and its various everyday undertakings, whether defined as 'art' or not. This brings the matter down to the level 
of the everyday business of ordinary people, which, as we noted before, is the ground from which notions of identity really arise. It is also the level at which the forces of globalization manifest in practice, whether in the form of Chinese manufactured products, American cultural exports, European tourists, or labour migration to Malaysia.

What the idea of critical regionalism suggests, and Eko shows us in practice, is that it is not only possible but can be highly productive, to search for resources - inspiration, models of practice, ideas, images and tools - in the physical and cultural environment in which we are inevitably rooted in one way or another. This may be as local as a particular village custom or as regional as the spread of bamboo or monsoonal climate. These will not necessarily coincide with the nation-state defined by politics and administration, and there is no reason to expect that they would, given the cultural and environmental arbitrariness of the boundaries of colonial states. But what Eko (and probably others) has shown, is a way of addressing these issues by way of negotiating art worlds. This in turn emerges primarily out of a deep immersion in local culture, history and environment, but is informed equally by a critical engagement with global modernity. We are talking, however, of the work of one man and a concept developed, ironically, as Keith Eggener (2002: 228) observes, by non-Indonesian intellectuals. How can these be applied to identity and art worlds at a national scale?

If we return to the fundamental dilemma of the Indonesian nation, whether at the level of identity or of administration, that is, its ongoing struggle to integrate populations of diverse language, ethnicity, religion and economic circumstance, then critical regionalism provides a conceptual model and Eko's work a practical one, albeit in the language of art, of how individuals and communities can imagine themselves and other Indonesians in ways less bounded by religion, ethnicity or economic circumstance. Such regional imaginings can be as large as the nation, and they form the basis of the national identity of at least one successful and cosmopolitan Indonesian. There seems to be no reason why they could not do so for others, and for communities of various scales. That such identities are not necessarily limited by the boundaries of the nation suggests also a form of extra-national, regional identity that may have the potential to do more good than harm in globalizing southeast Asia.

Graeme MacRae teaches Social Anthropology at the Auckland campus of Massey University. His research has been largely in Indonesia and has recently 
focused on development and environmental issues as well as architecture. His work may be found at http://graememacrae.wordpress.com. Email: G.S.Macrae@massey.ac.nz

\section{NOTES}

1 This paper is developed from one first presented at a symposium on 'Globalisation and National Identity in Asia', at Victoria University of Wellington, 29-30 November 2009. My thanks to the organizers, Stephen Epstein, Brian Moloughney and Sekar Bandhyopyay as well as all the participants for helpful feedback. It is also the indirect fruit of regular field research in Indonesia since 1993. This was facilitated in the first instance by the Indonesian Institute of Sciences (LIPI) and Universitas Udayana and has been funded partly by Auckland and Massey Universities.

2 Nasakom $=$ Nas(ionalisme $)+\mathrm{A}($ gama $)+$ Kom(unisme)

3 This resonates with Hannah le Roux's suggestions of an inherent ambivalence at the heart of all post-colonial architectures (2004: 447-450).

4 This section is based on the materials referenced in it, but also on a series of conversations (in mixed Indonesian and English) with Eko, over the years 2004-2009, usually in the course of meandering journeys around Jogjakarta to visit one or more of his projects or clients and find good places to eat. I am grateful to Eko, his wife Rina and his assistant/ protege Novi, for their friendship, hospitality and generosity over the years.

5 This passage is part translation, part interpretation of Eko's mini-essay, English and Indonesian versions of which form part of the exhibition invitation (Prawoto 2008a).

6 For a more detailed discussion of this project, see MacRae 2008.

7 Eko prefers to characterize the proper role of the architect by way of analogy with a midwife (bidan).

\section{REFERENCES}

Acciaoli, G. 1985. 'Culture as Art: From Practice to Spectacle in Indonesia'. Canberra Anthropology 8(1-2): 148-172.

Allerton, C. 2003. 'Authentic Housing, Authentic Culture? Transforming a Village into a "tourist site" in Manggarai, Eastern Indonesia'. Indonesia and the Malay World 31(89): 119-128.

Anderson, B. 2006. Language and Power: Exploring Political Cultures in Indonesia. Jakarta and Kuala Lumpur: Equinox.

Anderson, B. 1996. Imagined Communities: Reflections on the Origin and Spread of Nationalism. London: Verso.

Buehler, M. 2007. 'Local Elite Reconfiguration in post-New Order Indonesia: The 2005 Election of District Government Heads in South Sulawesi', Review of Indonesian and Malaysian Affairs 41(1): [119]-147.

Colquhoun, A. 1997. 'The Concept of Regionalism'. In Postcolonial Spaces, edited by G. B. Nalbantoglu and W. C. Thai, 13-23. New York: Princeton Architectural Press.

de Vletter, M. 2006. 'Tradition and Modernity in the Netherlands East Indies'. In The Past in the Present: Architecture in Indonesia, edited by P. J. M. Nas, 113-122. Rotterdam: NAi. 
Dovey, K. and E. Permansari. 2010. 'Monas and Merdeka Square'. In Becoming Places: Urbanism/Architecture/Identity/Power, by K. Dovey, 153-165. London: Routledge.

Easterling, K. 2005. Enduring Innocence: Global Architecture and its Political Masquerades. Cambridge: MIT Press.

Eggener, K. L. 2002. 'Placing Resistance: A Critique of Critical Regionalism'. Journal of Architectural Education 55(4): 228-238.

Errington, S. 1998. The Death of Authentic Primitive Art and Other Tales of Progress. Berkeley: University of California Press.

Frampton, K. 1983. 'Towards a Critical Regionalism: Six Points for an Architecture of Resistance'. In The Anti-Aesthetic. Essays on Postmodern Culture, edited by Hal Foster, 16-30. Seattle: Bay Press.

Frampton, K. 2007. 'Critical Regionalism: Modern Architecture and Cultural Identity'. In Modern Architecture: A Critical History (4 $4^{\text {th }}$ ed.), by K. Frampton, 314-327. London: Thames and Hudson.

Gittus, E. J. 2002. 'Berlin as a Conduit for the Creation of German National Identity at the End of the Twentieth Century'. Space \& Polity 6(1): 91-115.

Goad, P., A. Pieris, and P. Bingham-Hall. 2004. New Directions in Tropical Asian Architecture. Balmain, NSW, Australia: Pesaro Publishing.

Hartoonian, G. 2006. 'Critical Regionalism Reloaded'. Fabrications; Journal of the Society of Architectural Historians, Australia and New Zealand 16(2): 122-139.

Hitchcock, M. 1997. 'Indonesia in Miniature' In Images of Malay-Indonesia Identity, edited by Michael Hitchcock and Victor T. King, 227-235. Kuala Lumpur: Oxford University Press.

Hitchcock, M. and V. King. 1997. 'Introduction: Malay-Indonesian Identities'. In Images of Malay-Indonesia Identity, edited by Michael Hitchcock and Victor T. King, 1-18. Kuala Lumpur: Oxford University Press.

Kahn, J. 2009. 'State, Region and the Politics of Recognition: Towards Cosmopolitan Models of Political Integration'. In The Politics of the Periphery in Indonesia: Social and Geographical Perspectives, edited by M. Sakai, G. Banks and J. H. Walker, 14-38. Singapore: NUS Press.

Kusno, A. 2000. Behind the Postcolonial: Architecture, Urban Space and Political Culture in Indonesia. London: Routledge.

Leclerc, J. 1997. 'Jakarta in Sukarno's Image'. In Images of Malay-Indonesia Identity, edited by Michael Hitchcock and Victor T. King, 203-208. Kuala Lumpur: Oxford University Press.

Le Roux, H. 2004. 'Building on the Boundary - Modern Architecture in the Tropics'. Social Identities 10(4): 439-453.

Lefaivre, Liane, and Alexander Tzonis. 2003. Critical Regionalism: Architecture and Identity in a Globalized World. Munich: Prestel.

Lefaivre, L. 2003. 'Critical Regionalism. A Facet of Modern Architecture Since 1945'. In Critical Regionalism: Architecture and Identity in a Changing World, edited by L. Lefaivre and A. Tzonis, 24-56, Munich: Prestel.

Lico, G. 2003. Edifice Complex: Power, Myth and Marcos State Architecture. Manila: Ateneo de Manila University Press.

Macdonald, G. M. 1995. 'Indonesia's Medan Merdeka: National Identity and the Built Environment'. Antipode 27(3): 270-293.

MacRae, G. 2008. 'Could the System Work Better? Scale and Local Knowledge in Humanitarian Relief'. Development in Practice 18(2): 190-200.

MacRae, G. and S. Parker. 2002. 'Would the Real Undagi Please Stand Up? On the Social Location of Balinese Architectural Knowledge'. Bijdragen tot de Taal-Land-en Volkenkunde 158(2): 253-281. 
Mahatmanto. 2008. 'Drawing Lines Building Space' (Menarik Garis Membangun Ruang). In 2 eyes $x 50$ years $=100$ sketches, by E. Prawoto, 14-19. Jogjakarta: Duta Wacana University Press.

Nas, P. 1993. 'Jakarta, City Full of Symbols'. In Urban Symbolism, edited by P. Nas, 13-37. Leiden: Brill.

Nas, P. 2003. 'Ethnic Identity in Urban Architecture: Generations of Architects in Banda Aceh'. In Indonesian Houses: Volume 1: Tradition and Transformation in Vernacular Architecture, edited by P. Nas, 133-153. Leiden: KITLV.

Pangarsa, G. W. 2008. Arsitektur untuk Kemanusiaan: teropong Visual Culture atas Karyakarya Eko Prawoto. Surabaya: PT Wastu Lanus Grafika.

Pemberton, J. 1994a. On the Subject of 'Java'. Ithaca: Cornell University Press.

Pemberton, J. 1994b. 'Recollections from "Beautiful Indonesia" (Somewhere Beyond the Postmodern)'. Public Culture 6: 241-262.

Plattner, S. 1996. High Art Down Home. Chicago: Chicago University Press.

Prakash, V. 1997. 'Identity Production in Postcolonial Indian Architecture: Re-covering What We Never Had'. In Postcolonial Spaces, edited by G. B. Nalbantoglu and W. C. Thai, 39-52. New York: Princeton Architectural Press.

Prawoto, E. 2008a. Untitled essay in catalogue for exhibition Leng/Lung. Jogjakarta: Cemeti Art House.

Prawoto, E. 2008b. 2 eyes $x 50$ years $=100$ sketches. Jogjakarta: Duta Wacana University Press.

Raharjo, W. 2010. 'Becoming Prosperous: Informal Urbanism in Yogyakarta'. In Becoming Places: Urbanism/Architecture/Identity/Power, by K. Dovey, 79-102. London: Routledge.

Reid, A. 2002. 'Island of the Dead. Why do Bataks Erect Tugu?' In The Potent Dead: Ancestors, Saints and Heroes in Contemporary Indonesia, edited by H. Chambert-Loir and A. Reid, 88-102. Sydney and Honolulu: Allen and Unwin and University of Hawaii Press.

Rudofsky, B. 1964. Architecture Without Architects: An Introduction to Non-Pedigreed Architecture. New York: Museum of Modern Art.

Sakai M., G. Banks and J. H.Walker. 2009. 'Introduction: The Place of the Periphery'. In The Politics of the Periphery in Indonesia: Social and Geographical Perspectives, edited by M. Sakai, G. Banks, and J. H. Walker, 1-13. Singapore: NUS Press.

Stoller, P. 2009. The Power of the Between: An Anthropological Odyssey. Chicago: University of Chicago Press.

Sudjic, D. 2005. The Edifice Complex: How the Rich and Powerful Shape the World. London: Allen Lane.

Tsing A. L. 2005. Friction: An Ethnography of Global Connection. Princeton, NJ: Princeton University Press.

Tzonis, A. 2003. 'Introducing an Architecture of the Present: Critical Regionalism and the Design of Identity'. In Critical Regionalism: Architecture and Identity in a Changing World, edited by L. Lefaivre and A. Tzonis, 10-21, Munich: Prestel.

Vellinga, M. 2003. 'The Use of Houses in a Competition for Status: The Case of Abai Sangir (Minangkabau)'. In Indonesian Houses: Volume 1: Tradition and Transformation in Vernacular Architecture, edited by P. Nas, 155-176. Leiden: KITLV.

Waterson, R. 1997. The Living House: An Anthropology of Architecture in South-East Asia. London: Thames and Hudson. 